\title{
PROFIL KEMANDIRIAN SISWA SMA BERDASARKAN URUTAN KELAHIRAN DAN IMPLIKASINYA TERHADAP BIMBINGAN DAN KONSELING
}

\author{
Munggarani Ramadhan ${ }^{1(a)}$ dan Ipah Saripah ${ }^{1}$
}

\begin{abstract}
Autonomy Profile of Senior High School Student Based on Birth Order and Implication from Guidance and Counseling. The research was motivated by the lack of autonomy of students, where they so many factor influence which is birth order is among them. Autonomy is the readinnes of individuals to regulate, control, and manage themselves without depend on adult person and responnsibility for decision. The purpose of research to describe autonomy of students based on birth order. The research approach using a quantitative approach with descriptive method. The population in this reseacrh is a class XII student of SMA AI Muttaqin Fullday School Tasikmalaya Academic Year 2015/2016. The results showed a picture of autonomy of students based on birth order in higher category. Recommendations research showed to teachers Guidance and Counseling and further research.
\end{abstract}

Keywords: Autonomy, Birth order.

INDONESIAN JOURNAL OF EDUCATIONAL COUNSELING

Website: http://ojs.ejournal.id/index.php/ijec

Permalink: http://ojs.ejournal.id/index.php/ijec/article/view/12

How to cite (APA): Ramadhan, M., \& Saripah, I. (2017). Profil kemandirian siswa SMA berdasarkan urutan kelahiran dan implikasinya terhadap bimbingan dan konseling. Indonesian Journal of Educational Counseling, 1(2), 145-162.

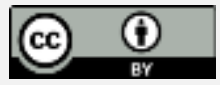

This is an open access article distributed under the terms of the Creative Commons Attribution 4.0 International License, which permits unrestricted use, distribution, and reproduction in any medium, provided the original work is properly cited.

\section{PENDAHULUAN}

Kemandirian merupakan hal penting bagi kehidupan setiap individu. Steinberg (1995: 285) menafsirkan kemandirian sebagai kemampuan menguasai diri. Kemampuan menguasai diri ini bukan hanya diperlukan oleh orang dewasa, kemampuan tersebut perlu dikembangkan oleh remaja agar mereka tidak selalu bergantung kepada orang tua atau orang dewasa lainnya,serta mampu mengambil keputusan sendiri dan konsisten terhadap keputusan tersebut.

Pencapaian kemandirian bagi remaja merupakan sesuatu hal yang tidak mudah, kesulitannya terletak pada upaya pemutusan ikatan infantile yang telah berkembang dan dinikmati dengan penuh rasa nyaman selama masa kanakkanak (Budiman, 2010: 4). Pada masa remaja akan terjadi perkembangan

\footnotetext{
${ }^{1}$ Departemen Psikologi Pendidikan dan Bimbingan, FIP Universitas Pendidikan Indonesia.

a Email: igarppm06@gmail.com.
} 
psikososial dari arah lingkungan keluarga menuju lingkungan sosial. Mereka berusaha melakukan pelepasan-pelepasan atas keterikatan yang selama ini dialami pada masa kanak-kanak saat segalanya sering diatur oleh orang tua atau orang dewasa yang ada disekitarnya.

Pendapat Hurlock (1980: 220) terdapat tiga faktor yang mempengaruhi kemandirian yaitu; pola asuh orang tua, jenis kelamin, dan urutan kelahiran (birth order). Salah satu faktor yang menjadi fokus penelitian ini yaitu pengaruh urutan kelahiran (birth order) terhadap kemandirian remaja.

Menurut Covey (2007: 64), urutan kelahiran dan interpretasi terhadap posisi seseorang dalam keluarga berpengaruh terhadap cara seseorang berinteraksi. Urutan kelahiran, selain membentuk karakter tertentu, juga memunculkan sindrom tertentu. Menurut Hurlock (2001: 62) status anak dalam keluarga menurut urutan kelahiran dibagi menjadi anak sulung, anak bungsu, atau anak diantara kakak dan adiknya. Anak dengan statusnya masing-masing di dalam keluaraga mempunyai karakteristik yang berbeda satu sama lain.

Hurlock (Rini, 2012: 62) mengemukakan, terdapat beberapa persamaan sindrom antara anak sulung dan anak bungsu. Anak sulung seringkali lebih mandiri, sedangkan anak bungsu mempunyai sindrom manja, merasa tidak mampu dan rendah diri, dan tidak bertanggung jawab.

Berdasarkan pendapat Hurlock (1978: 201) tentang sindrom antara anak sulung dan anak bungsu juga terdapat indikasi munculnya ketidakmandirian pada anak sulung dan anak bungsu. Anak kedua yang memiliki posisi terjepit sehingga anak kedua atau anak tengah harus berkompetisi agar mendapat perhatian dari orang tua membuat anak kedua cenderung dapat lebih mandiri. Anak tunggal yang lahir lebih dulu dari adik-adiknya dan menjadi pengalaman pertama bagi orang tuanya biasanya memperoleh perhatian berlebih yang dapat membuat anak tunggal menjadi manja. Pada kehidupan di masyarakat sering dijumpai perbedaan perilaku orang tua yang diberikan terhadap anakanaknya berdasarkan urutan kelahiran, sehingga perbedaan perilaku tersebut akan menghasilkan perkembangan yang berbeda. Hal tersebut memunculkan pertanyaan tentang kemandirian anak sulung, anak tengah, dan anak bungsu

Adapun penuturan Guru BK, fenomena perbedaan kemandirian siswa menurut urutan kelahiran terjadi di Kelas XII SMA AL Muttaqin Fullday School. Di kelas tersebut terdapat beberapa siswa yang di keluarganya merupakan anak sulung yang terlihat lebih mandiri; dapat mengambil keputusan sendiri, dapat menghadapi masalah sendiri, dan cenderung jarang merepotkan orang lain yang ada di sekitarnya. Anak tengah lebih senang berkompromi dengan teman-temannya sebelum ia bertindak ataupun memutuskan sesuatu. Anak 
bungsu lebih egosentris, dan terkadang tidak sabaran dalam menyikapi suatu masalah.

Siswa SMA merupakan individu yang sedang berkembang memiliki potensi untuk mengembangkan perilaku mandiri. Sebagai lembaga pendidikan sekolah bukan hanya bertanggung jawab dalam membentuk siswa yang berprestasi di bidang akademik. melainkan berperan juga dalam mengenbangkan perilaku siswa yang positif. Salah satu perilaku positif adalah kemandirian. Sekolah bertugas mendidik dan mengajar, serta memperbaiki dan memperhalus tingkah laku anak didik yang dibawa dari keluarganya (Yudha, 2012: 23).

Kemandirian merupakan masalah psikososial yang muncul selama siklus kehidupan. Perkembangan kemandirian sama pentingnya seperti perkembangan identitas diri yaitu remaja memahami makna "siapa aku" yang dipengaruhi oleh pandangan orang-orang sekitarnya serta pengalamanpengalaman pribadinya sehingga akan membentuk perilakunya kelak sebagai orang dewasa (Irwanto, 2002: 48). Pentingnya perkembangan kemandirian dikemukakan pula oleh Maslow (Alwisol, 2004: 260) yang mengungkapkan bahwa kemandirian merupakan salah satu kebutuhan meta yaitu kebutuhan untuk mengaktualisasikan diri, tidak tergantung dan mampu menentukan diri sendiri. Dalam susunan hierarki kebutuhan Maslow, kemandirian adalah salah satu cara untuk memperoleh harga diri dan kemandirian akan menjadikan seseorang menghargai dirinya sendiri.

Erikson (Steinberg, 2002: 289), percaya bahwa kemandirian adalah isu utama pada masa remaja. Kemandirian berasal dari kata mandiri yang berarti berdiri sendiri dan diartikan pula sebagai suatu keadaan dimana seorang individu tidak bergantung pada orang lain. Menjadi individu yang mandiri adalah salah satu tugas perkembangan yang mendasar pada masa remaja, karena kemandirian merupakan dasar untuk menjadi individu dewasa. Budiman (2010: 110) mengemukakan bahwa kemandirian akan mendasari orang dewasa dalam menentukan sikap dan keputusan, mengidentifikasi pemecahan masalah, serta keajegan dalam menentukan dan melakukan prinsip-prinsip kebenaran dan kebaikan.

Menurut Steinberg (1999: 289) terdapat tiga aspek kemandirian remaja: 1) Kemandirian emosional, yakni seberapa besar ketidaktergantungan individu terhadap dukungan emosional orang lain, terutama orang tua dalam mengelola dirinya; 2) Kemandirian Perilaku, merupakan kemampuan individu dalam menentukan pilihan dan mampu mengambil keputusan untuk pengelolaan dirinya; 3) Kemandirian nilai, yakni kemampuan individu untuk menolak tekanan atau tuntutan orang ain yang berkaitan degan keyakinan dalam bidang nilai. 
Menurut Hurlock (1990), faktor-faktor yang mempengaruhi kemandirian: 1) Pola asuh orang tua; 2) Jenis kelamin; dan 3) Urutan kelahiran anak. Orang tua dengan pola asuh yang demokratis sangat merangsang kemandirian anak, yaitu peran orang tua sebagai pembimbing yang memperhatikan terhadap aktivitas dan kebutuhan anak terutama dalam hal pergaulannya di lingkungan sekitar pun di sekolah. Anak yang berkembang dengan tingkah laku maskulin lebih mandiri daripada anak yang mengembangkan pola perilaku feminim.

Urutan kelahiran adalah ilmu untuk memahami keberadaan seseorang di garis keluarga, apakah seseorang itu anak pertama, kedua, atau ketiga, urutan keberapapun, itu memengarui hidup seseorang dalam banyak hal, (Leman, 2001: 14). Urutan kelahiran dalam keluarga berpengaruh terhadap kehidupan seseorang baik dalam hubungan dengan keluarga di rumah, karir, dan lingkungan masyarakat, seperti yang dikatakan oleh Leman (2001: 15).

\section{Anak Pertama}

Anak sulung atau anak pertama secara resmi didefinisikan sebagai yang tertua di keluarga, (Leman, 2001: 83). Anak tertua berarti anak yang dilahirkan pertama sebelum saudara-saudaranya. Anak pertama memilki banyak keunikan dalam dirinya, sebagaimana yang dikatakan Leman (2001: 83) , anak pertama adalah orang yang sangat berbeda ketimbang anak yang lahir sebagai anak yang lahir kemudian. Biasanya, orang tua sangat bahagia ketika lahir anak pertama mereka dan mereka akan mencurahkan seluruh waktu dan perhatian pada bayi yang baru lahir. Maka dari itu anak pertama biasanya menerima perhatian yang penuh dari orang tuanya.

\section{Anak Kedua}

Menurut Leman, (2001: 175), definisi resmi mengenai anak tengah adalah seseorang yang lahir di suatu tempat di antara yang pertama atau yang tertua di keluarga dan yang paling akir-secaara harfiah anak bungsu. Anak kedua memiliki situasi yang unik pula. Dia tidak pernah mengalami kekuasaan penuh dan posisi vokal seperti yang dialami anak pertama, Anak tengah merasa mereka lahir terlambat untuk mendapatkan hak-hak istimewa dan perlakuan istimewa yang tampaknya telah diwarisi anak sulung, (Leman, 2001: 176). Mungkin orang tuapun telah berubah seirig dengan waktu kelahiran anak kedua. Bayi kedua tidak membawa sesuatu yang baru seperti anak pertama; mereka lebih santai dalam menghadapi anak kedua atau anak tengah.

\section{Anak Terakhir}

Anak-anak termuda dalam keluarga biasanya merupakan para pemikat yang ramah, penipu-penipu yang rupawan, (Leman, 2001: 196). Anak yang paling muda atau anak bungsu merupakan anak yang paling akhir lahir, ia tidak 
pernah merasa shock dengan kedudukan anak lain yang lebih tinggi. Seperti yang diungkapkan Leman (2001: 198), Anak-anak bungsu benar-benar menyadari bahwa merekalah yang termuda, terkecil, terlemah, dan yang paling akhir diperlengkapi untuk bersaing dalam kehidupan.

Berdasarkan latar belakang di atas, maka masalah yang menarik perhatian berkenaan dengan kemandirian remaja yaitu terdapat perbedaan kemandirian siswa berdasarkan urutan kelahiran dalam keluarga, sehingga penting untuk dilakukan penelitian dengan judul "Profil Kemandirian Siswa SMA Berdasarkan Urutan Kelahiran dan Implikasinya Bagi Bimbingan dan Konseling".

\section{METODE}

Pendekatan yang digunakan dalam penelitian ini adalah pendekatan kuantitatif, yaitu upaya menganalisisis populasi tertentu untuk mendapatkan angka secara numerikal yang digunakan untuk mengetahui gambaran kemandirian peserta didik Kelas XII SMA Al Muttaqin Fullday School Tasikmalaya Tahun Ajaran 2016/2017. Populasi dalam penelitian ini berjumlah 120 orang siswa.

Data hasil penelitian berupa skor dan diproses melalui pengolahan statistik, selanjutnya dideskripsikan untuk mendapatkan gambaran kemandirian pesertadidik berdasarkan urutan kelahiran.

Metode yang digunakan dalam penelitian ini adalah deskriptif. Hasil dari penelitian ini yaitu diperolehnya kecenderungan kemandirian siswa berdasarkan urutan kelahiran, yang terdiri dari anak sulung, anak tengah, dan anak bungsu. Pengumpulan data yang digunakan, yaitu non-tes dengan menggunakan instrumen berupa kuesioner (angket). Instrumen yang digunakan dakan pengumpulan data adalah angket tertutup untuk menungkap kemandirian peserta didik. Instrumen kemandirian ini terdiri dari tiga aspek kemandirian yaitu, kemandirian emosi, kemandirian perilaku, dan kemandirian nilai. Kecenderungan respons dari responden berdasarkan format skala Likert dengan lima alternatif jawaban yaitu, Sangat Sesuai (SS), Sesuai (S), Kurang Sesuai (KS), Tidak Sesuai (TS), dan Sangat Tidak Sesuai (STS).

Data kemandirian siswa dalam penelitian dapat diungkap dengan instrumen kemandirian yang dikembangkan berdasarkan kisi-kisi yang dirumuskan oleh peneliti. Perumusan kisi-kisi instrumen disajikan dalam Tabel 1. 
Tabel 1. Kisi-kisi Instrumen Kemandirian

\begin{tabular}{|c|c|c|c|}
\hline No. & Aspek & Sub-aspek & Indikator \\
\hline \multirow[t]{6}{*}{1.} & \multirow[t]{6}{*}{$\begin{array}{l}\text { Kemandirian } \\
\text { Emosi }\end{array}$} & De-ldealized & $\begin{array}{l}\text { Remaja memandang orang tua bukan } \\
\text { orang yang sempurna }\end{array}$ \\
\hline & & Parent as a people & $\begin{array}{l}\text { Remaja mampu melihat orang tua } \\
\text { sama seperti orang lain secara umum }\end{array}$ \\
\hline & & \multirow[t]{2}{*}{ Non- dependency } & $\begin{array}{l}\text { Remaja mampu membuat keputusan } \\
\text { sendiri tanpa melibatkan orang lain }\end{array}$ \\
\hline & & & $\begin{array}{l}\text { Remaja mampu bertanggung jawab } \\
\text { atas keputusannya }\end{array}$ \\
\hline & & \multirow[t]{2}{*}{ Individuation } & $\begin{array}{l}\text { Remaja merasa sebagai seseorang } \\
\text { yang memiliki pkiran an perasaan } \\
\text { yang berbeda dengan orang tua. }\end{array}$ \\
\hline & & & Remaja memiliki privasi \\
\hline \multirow[t]{6}{*}{2.} & \multirow[t]{6}{*}{$\begin{array}{l}\text { Kemandirian } \\
\text { Perilaku }\end{array}$} & \multirow{3}{*}{$\begin{array}{l}\text { Kemampuan } \\
\text { mengambil } \\
\text { keputusan }\end{array}$} & $\begin{array}{l}\text { Remaja mampu mengetahui sumber } \\
\text { masalah }\end{array}$ \\
\hline & & & $\begin{array}{l}\text { Remaja sadar akan resiko yang akan } \\
\text { dihadapi }\end{array}$ \\
\hline & & & $\begin{array}{l}\text { Remaja mempertimbangkan berbagai } \\
\text { hal yang akan ia putuskan }\end{array}$ \\
\hline & & \multirow{2}{*}{$\begin{array}{l}\text { Tidak mudah goyah } \\
\text { terhadap pengaruh } \\
\text { pihak lain }\end{array}$} & $\begin{array}{l}\text { Remaja memiliki ketegasan terhadap } \\
\text { diri sendiri }\end{array}$ \\
\hline & & & Remaja tidak mudah terpengaruh \\
\hline & & $\begin{array}{l}\text { Perubahan dalam } \\
\text { rasa }\end{array}$ & Remaja percaya diri \\
\hline \multirow[t]{4}{*}{3.} & \multirow[t]{4}{*}{$\begin{array}{l}\text { Kemandirian } \\
\text { Nilai }\end{array}$} & \multirow[t]{2}{*}{ Abstract belief } & $\begin{array}{l}\text { Remaja mampu membedakan yang } \\
\text { benar dan salah }\end{array}$ \\
\hline & & & $\begin{array}{l}\text { Remaja memiliki keyakinan } \\
\text { beragama }\end{array}$ \\
\hline & & Principal belief & Remaja berperilaku sesuai prinsip \\
\hline & & Independent & $\begin{array}{l}\text { Remaja bertindak sesuai dengan } \\
\text { keyakinan sendiri }\end{array}$ \\
\hline
\end{tabular}

Sebelum disebarkan dan digunakan sebagai alat pengambil data, instrumen kemandirian melalui tahapan uji kelayakan instrumen, yakni: 1) uji keterbacaan; 2) uji reliabilitas; dan 3) uji validitas. Uji keterbacaan ditujukan untuk mengetahui sejauh mana instrumen dapat dipahami oleh peserta didik kelas XII SMA AI Muttaqin Fullday School. Uji keterbacaan instrumen dilakukan kepada beberapa peserta didik kelas XII SMA AI Muttaqin Fullday School.

Reliabilitas instrumen ditunjukkan sebagai derajat keajegan (konsistensi) skor yang diperoleh oleh subjek penelitian dengan instrumen yang sama dalam kondisi berbeda. Uji reliabilitas dalam penelitian ini dilakukan dengan menggunakan rumus Croanbach's Alpha. Hasil dari uji reliabilitas instrumen kemandirian menunjukan nilai reliabilitas sebesar 0,873 (sangat tinggi). Hasil tersebut menunjukan bahwa instrumen dikatakan reliabel dengan derajat keterandalan sangat tinggi. 
Pengujian validitas yang dilakukan dalam penelitian adalah dengan mengkorelasikan skor butir dengan skor total. Menurut Azwar, (2012: 92) sebuah item dinyakan valid ketika item dapat mengukur secara tepat atribut yang hendak diukur. Semakin tinggi nilai validitas, maka menunjukkan bahwa item tersebut semakin valid. Uji validitas item dilakukan dengan menggunakan rumus korelasi Spearman-Brown. Berdasarkan hasil dari uji validitas item, pada instrumen kemandirian menunjukkan bahwa 41 item dinyatakan valid dan 10 item dinyatakan tidak valid.

Analisis data dilakukan dengan kategorisasi data untuk melihat kecenderungan umum dan menghitung banyaknya siswa masuk ketegori pada variabel kemandirian. Kategorisasi data diawali dengan mengelompokan data menjadi tiga kategori dengan mengubah lima pilihan jawaban pada instrumen menjadi tiga ketegori. Adapun kategori yang digunakan dalam menunjukan tingkat kemandirian adalah "tinggi", "sedang", dan "rendah".

Kecenderungan umum diperoleh melalui median dari data yang disesuaikan dengan kategori yang telah dibuat. Rumus median digunakan karena data yang diperoleh dari instrumen berbentuk ordinal. Untuk menghitung frekuensi dan persentase siswa kelas XII SMA AI Muttaqin Fullday School Tahun Ajaran 2016/2017 pada setiap kategori dalam variabel bebas urutan kelahiran dilakukan dengan melakukan distribusi frekuensi. Adapun interpretasi dari setiap kategori kemandirian disajikan pada Tabel 2.

Tabel 2. Interpretasi Skor Kategori Kemandirian

\begin{tabular}{lll}
\hline Rentang Skor & Kategori & \multicolumn{1}{c}{ Interpretasi } \\
\hline$>3,33$ & Tinggi & $\begin{array}{l}\text { Siswa pada kategori tinggi menunjukan } \\
\text { kesesuaian dengan lebih dari 12 indikator pada } \\
\text { aspek kemandirian emosi, kemandirian perilaku, } \\
\text { dan kemandirian nilai. }\end{array}$ \\
\hline $1,68-3,33$ & Sedang & $\begin{array}{l}\text { Siswa pada kategori sedang menunjukan } \\
\text { kesesuaian dengan sekitar } 6 \text { sampai 12 indikator } \\
\text { pada aspek kemandirian emosi, kemandirian } \\
\text { perilaku, dan kemandirian nilai. }\end{array}$ \\
\hline$<1,68$ & Rendah & $\begin{array}{l}\text { Siswa pada kategori rendah menunjukan } \\
\text { kesesuaian dengan sekitar } 6 \text { indikator pada aspek } \\
\text { kemandirian emosi, kemandirian perilaku, dan } \\
\text { kemandirian nilai. }\end{array}$ \\
\hline
\end{tabular}

\section{HASIL DAN PEMBAHASAN}

Hasil penelitian menunjukkan mayoritas siswa memiliki kategori kemandirian yang tinggi yaitu sebanyak $75,8 \%$ dengan jumlah frekuensi 91 orang dari keseluruhan siswa sebanyak 120 orang, yang berarti siswa mampu 
mengembangkan kemandirian secara emosi, perilaku, dan nilai. Sisanya sejumlah $24,2 \%$ atau 29 orang yang berada pada kategori sedang yang berarti secara umum siswa cenderung cukup mampu untuk mandiri secara emosi, perilaku, dan nilai, dengan kata lain siswa pada kategori sedang, dapat diartikan telah mencapai tingkat kemandirian yang cukup optimal pada setiap aspeknya. Dan dari 120 siswa tidak ada yang berada pada kategori kemandirian rendah. Maka dari itu kemandirian siswa kelas XII SMA AI Muttaqin Fullday School sudah cukup optimal. Hal ini dapat dilihat dari hasil penelitian yang menunjukkan pesertaa didik tidak ada yang berada pada kategori rendah.

Hal tersebut sama dengan analisis Steinberg (Budiman, 2010: 5) jika remaja, terutama remaja awal mampu memutuskan simpul - simpul ikatan infantile maka ia akan melakukan separasi. Inilah yang merupakan dasar bagi pencapaian kemandirian terutama kemandirian yang bersifat independence. Oleh karena itu pada masa remaja suatu pergerakan kemandirian yang dinamis dari ketidakmandirian individu pada masa kanak-kanak menuju kemandirian yang lebih bersifat autonomy pada masa dewasa.

Dikatakan pula bahwa kemandirian siswa terlihat dalam bagaimana siswa tersebut mampu menunjukan kreatifitas, mampu berinisiatif, mengatasi hambatan, melakukan sesuatu dengan benar, gigih dalam berusaha, dan melakukan sesuatu sendiri tanpa bantuan orang lain, serta dapat menjalankan tugas-tugas kehidupannya. Hal tersebut sangat penting bagi siswa, karena akan menjadi modal utama untuk menghadapi tantangan-tantangan kehidupannya.

Siswa dengan kemandirian yang baik yaitu ditandai oleh kemampuan untuk melepaskan ikatan emosional dari orang tua, dapat mengambil keputusan dan menyesuaikan diri terhadap berbagai pengaruh orang lain serta memiliki rasa percaya diri untuk melaksanakan setiap keputusan berdasarkan prinsip-prinsip dalam diri individu.

Secara spesifik mengenai kecenderungan kemandirian siswa berdasarkan tiga aspek kemandirian yaitu kemandirian emosi, kemandirian perilaku, dan kemandirian nilai, dibahas secara rinci sebagai berikut.

\section{Aspek Kemandirian Emosi}

Rata-rata siswa memiliki kategori tinggi dalam aspek kemandirian emosi, yaitu sebanyak $63,3 \%$ dengan jumlah frekuensi 76 orang. Sedikitnya 44 orang atau $36,7 \%$ berada pada kategori sedang, dan tidak ada yang memiliki kategori rendah. Hal tersebut dapat diartikan bahwa sebagian besar siswa cenderung mampu dalam memandang orang tua bukan sebagai orang yang sempurna, 
melihat orang tua seperti orang lain pada umumnya, mampu membuat keputusan untuk menyelesaikan masalahnya tanpa mengandalkan orang tua, mampu bertanggung jawab atas keputusan yang diambil, siswa merasa sebagai individu yang memiliki pemikiran dan perasaan yang berbeda dengan orang tuanya dan siswa mampu menjaga privasi.

Hal ini senada dengan analisis Berk (Budiman, 2010: 6) bahwa konsekuensi dari semakin mampunya remaja mengurus dirinya sendiri maka waktu yang diluangkan orang tua terhadap anak semakin berkurang dengan sangat tajam. Proses ini sedikit besarnya memberikan peluang bagi remaja untuk mengembangkan kemandiriannya terutama kemandirian emosional.

Pada dasarnya, ketika manusia berada pada usia remaja kemandirian emosi sebaiknya harus sudah tercapai. Hal ini sesuai yang dikemukakan oleh William Kay (Yusuf, 2000: 72) bahwa salah satu tugas perkembangan pada masa remaja adalah mencapai kemandirian emosional dari orang tua atau figur-figur yang mempunyai otoritas. Kemandirian emosional merupakan hal penting dan menonjol pada masa remaja, namun buka merupakan kejadian tiba-tiba yang dialami oleh remaja. Kemandiiran emosional remaja berkembang sejak awal kehidupan di masa anak-anak melalui proses sosialisasi dalam lingkungan keluarga.

Sementara itu Steinberg (1993: 289), menyatakan bahwa menjelan akhir masa remaja, individu secara emosional tidak begitu tergantung pada orang tua mereka "lebih mandiri secara emosi" daripada ketika mereka masih anak-anak. Kita dapat melihatnya melalui berbagai cara. Pertama, para remaja umumnya tidak cepat atau serta merta meyampaikan perasaan mereja kepada orangtuanya jika mereka sedih, marah, atau jika membutuhkan bantuan. Kedua, mereka tidak memandang orang tua mereka sebagai orang yang mengetahui segalanya (all-knowing) atau menguasai segalanya (all-powerful). Ketiga, para remaja seringkali mempunayi perasaan yang kuat untuk menyelesaikan masalah dalam hubungan-hubungan di luar keluarga; mereka mempunyai perasaan yang lebih dekat dengan teman laki-laki atau teman perempuan daripada dengan orang tua mereka. Terakhir, para remaja mampu untuk melihat dan berinteraksi dengan orangtua mereka seperti dengan orang lain, tidak seperti dengan orangtua sendiri.

Steinberg dan ahli-ahli lainnya memandang proses perubaha hubungan itu sebagai prosees transformasi. Menurut mereka, meskipun para remaja dan orangtua mengubah hubungan emosional yang terbentuk pada masa anakanaknya, namun ikatan perasaan (emosional) mereka pada masa remaja, bagaimanapun tidak akan putus. Ini merupakan sebuah keistimewaan penting, karena ini berarti bahwa kemandirian emosional pada masa remaja itu 
mengalami tranfoemasi, bukan pemutusan hubungan keluarga. Remja memperoleh kemandirian secara emosional dari orang tua mereka tanpa timbul pemutusan hubungan diantara mereka (Colins, 1990; Hill \& Holmbeck, 1986; Steinberg, 2002: 290).

\section{Aspek Kemandirian Perilaku}

Berdasarkan hasil penelitian didapatkan bahwa gambaran umum pada aspek kemandirian perilaku adalah, mayoritas siswa sebanyak 67 orang atau 55,80\% berada pada kategori tinggi. Sisanya sedikitnya 53 orang atau $44,20 \%$ berada pada kategori sedang, dan tidak ada siswa yang berada pada kategori rendah.

Hal ini menggambarkan bahwa sebagian besar siswa cenderung memiliki kemampuan yang cukup optimal dalam meyakinan potensi yang dimiliki. Senada dengan yang dipaparkan oleh Widjaja (Budiman, 2010: 9) yang menyatakan kemandirian perilaku, khususnya kemampuan mandiri secara fisik sesungguhnya sudah berkembang sejak usia anak dan meningkat sangat tajam pada usia remaja.

Menurut Steinberg (Budiman, 2010: 9) ada tiga domain perilaku (behavioral autinomy) yang berkembang pada masa remaja. Pertama, mereka memiliki kemampuan mengambil keputusan yang ditandai oleh (a) menyadari adanya risiko dari tingkah lakunya, (b) memilih alternatif pemecahan masalah didasarkan atas pertimbangan sendiri dan orang lain dan (c) bertanggung jawab atas konsekuensi dari keputusan yang diambilnya. Kedua, mereja mempunyai kekuatan terhadap pengaruh pihak lai yang ditandai oleh (a) tidak mudah terpengaruh dalam situasi yang menuntut konformitas, (b) tidak mudah terpengaruh tekanan teman sebaya dan orang tua dalam mengambul keputusan, dan (c) memasuki kelompok sosial tanpa tekanan. Ketiga, mereka mempunyai rasa percaya diri (self reliance) yang ditandai oleh (a) merasa mampu memenuhi kebitihan sehari-hari di rumah dan di sekolah, (b) merasa mampu memenuhi tanggung jawab di rumah dan di sekolah, (c) merasa mmapu mengatasi sendiri masalahnya, (d) berani mengemukakan ide atau gagasan.

Berdasarkan pada hasil penelitian didapatkan bahwa mayoritas siswa berada pada kategori sedang, hal tersebut berarti kemandirian perilaku siswa tengah menuju pada penguasaan kemandirian perilaku yang tinggi. Artinya siswa pada kualifikasi sedang masih memerlukan bimbingan dari orang lain, atau bekum menunjukkan aspek-aspel kemandirian perilaku.

\section{Aspek Kemandirian Nilai}

Hasil penelitian pada aspek kemandirian nilai menunjukan mayoritas siswa sebanyak 116 atau $96,70 \%$ berada pada kategori tinggi,. Sedikitnya 4 orang 
siswa atau 3,3\% berada pada kategori sedang, dan tidak ada siswa yang berada pada kategori rendah.

Hal ini menunjukkan bahwa sebagian besar siswa sudah yang optimal dalam membedakan yang benar dan yang salah, memiliki keyakinan terhadap nilai keagamaan, bertindak sesuai dengan prinsip yang dapat dipertanggung jawabkan dalam bidang nilai, bertindak sesuai keyakinan dalam nilainya sendiri.

Hasil di atas diperkuat oleh pendapat dari Douvan \& Adelson (Aprilia, 2009: 120) menyebutkan, kemandirian nilai menunjuk kepada suatu pengertian mengenai kemampuan seseorang untuk mengambil keputusan-keputusan dan menetapkan pilihan yang lebih berpegang atas dasar prinsip-prinsip individual yang dimilikinya, daripda mengambil prinsip-prinsip dari irang lain. Dengan kata ain bahwa kemandirian nilai menggambarkan kemamouan remaja untuk mendukung atau menolak tekanan, permintaan maupun ajakan orang lain; dalam arti ia memiliki seperangkat prinsip tentang benar atau salah, tentang apa yang penting dan tidak penting.

Steinberg, (1993: 303-304) menjelaskan bahwa perkembangan kemandirian nilai sepanjang remaja ditandai oleh tiga aspek, yaitu: pertama, cara remaja dalam memikirkan segala sesuatu menjadi semakin bertambah abstrak (abstract belief); dan ketiga, keyakinan-keyakinan remaja ajan nilai menjadi semakin terbentuk dalam diri mereka sendiri dan bukan hanya dalam sistem nilai yang ditanamkan oleh orangtua atau orang dewasa lain (independent belief).

Sebagian besar perkembangan kemandirian nilai dapat ditelusuri pada karakteristik perubahan kognitif masa remaja. Penongkatan kemampuan rasional dan berkembangngnya kemamouan nerpikir hipotesis menimbulkan minat yang tinggi pada masalah-masalah ideologi dan filosofi serta lebih mendetail dalam melihat masalah ideologi dan filosofi. Perkembangan kemandirian nilai membawa perubahan-perubahan pada konsepsi remaja tentang moral, politik, ideoligi, dan persoalan agama (Steinberg, 1993: 304)

\section{Kemandirian Siswa Berdasarkan Urutan Kelahiran}

Secara spesifik mengenai gambaran kemandirian siswa berdasarkan aspekaspek yang digunakan untuk memiliki sikap mandiri yang meliputi kemandirian emosi, kemandirian perilaku, dan kemandirian yang akan dibahas secara rinci sebagai berikut. 
Tabel 2. Kemandirian Berdasarkan Urutan Kelahiran Secara Umum

\begin{tabular}{clrr}
\hline Urutan Kelahiran & Kategori & Frekuensi & Presentase \\
\hline Anak Sulung & Tinggi & 52 & $82,5 \%$ \\
\hline & Sedang & 11 & $17,5 \%$ \\
\hline & Rendah & 0 & $0,0 \%$ \\
\hline Anak Tengah & Tinggi & 19 & $79,2 \%$ \\
\hline & Sedang & 5 & $20,8 \%$ \\
\hline Anak Bungsu & Rendah & 0 & $0,0 \%$ \\
\hline & Tinggi & 20 & $60,6 \%$ \\
\hline & Sedang & 13 & $39,4 \%$ \\
\hline & Rendah & 0 & $0,0 \%$ \\
\hline
\end{tabular}

Tabel 3. Kemandirian Berdasarkan Urutan Kelahiran Per-aspek

\begin{tabular}{|c|c|c|c|c|}
\hline $\begin{array}{c}\text { Urutan } \\
\text { Kelahiran }\end{array}$ & Aspek & Kategori & Frekuensi & Presentase \\
\hline \multirow[t]{9}{*}{ Anak Sulung } & \multirow{3}{*}{$\begin{array}{l}\text { Kemandirian } \\
\text { Emosi }\end{array}$} & Tinggi & 40 & $63,5 \%$ \\
\hline & & Sedang & 23 & $36,5 \%$ \\
\hline & & Rendah & 0 & $0,0 \%$ \\
\hline & \multirow{3}{*}{$\begin{array}{l}\text { Kemandirian } \\
\text { Perilaku }\end{array}$} & Tinggi & 42 & $65,1 \%$ \\
\hline & & Sedang & 22 & $34,9 \%$ \\
\hline & & Rendah & 0 & $0,0 \%$ \\
\hline & \multirow{3}{*}{$\begin{array}{l}\text { Kemandirian } \\
\text { Nilai }\end{array}$} & Tinggi & 61 & $96,8 \%$ \\
\hline & & Sedang & 2 & $3,2 \%$ \\
\hline & & Rendah & 0 & $0,0 \%$ \\
\hline \multirow[t]{9}{*}{ Anak Tengah } & \multirow{3}{*}{$\begin{array}{l}\text { Kemandirian } \\
\text { Emosi }\end{array}$} & Tinggi & 17 & $70,8 \%$ \\
\hline & & Sedang & 7 & $29,2 \%$ \\
\hline & & Rendah & 0 & $0,0 \%$ \\
\hline & \multirow{3}{*}{$\begin{array}{l}\text { Kemandirian } \\
\text { Perilaku }\end{array}$} & Tinggi & 18 & $75 \%$ \\
\hline & & Sedang & 6 & $25 \%$ \\
\hline & & Rendah & 0 & $0,0 \%$ \\
\hline & \multirow{3}{*}{$\begin{array}{l}\text { Kemandiran } \\
\text { Nilai }\end{array}$} & Tinggi & 23 & $95,8 \%$ \\
\hline & & Sedang & 1 & $4,2 \%$ \\
\hline & & Rendah & 0 & $0,0 \%$ \\
\hline \multirow[t]{9}{*}{ Anak Bungsu } & \multirow{3}{*}{$\begin{array}{l}\text { Kemandirian } \\
\text { Emosi }\end{array}$} & Tinggi & 19 & $57,6 \%$ \\
\hline & & Sedang & 14 & $42,4 \%$ \\
\hline & & Rendah & 0 & $0,0 \%$ \\
\hline & \multirow{3}{*}{$\begin{array}{l}\text { Kemandirian } \\
\text { Perilaku }\end{array}$} & Tinggi & 8 & $24,2 \%$ \\
\hline & & Sedang & 25 & $75,8 \%$ \\
\hline & & Rendah & 0 & $0,0 \%$ \\
\hline & \multirow{3}{*}{$\begin{array}{l}\text { Kemandirian } \\
\text { Nilai }\end{array}$} & Tinggi & 32 & $97,0 \%$ \\
\hline & & Sedang & 1 & $3,0 \%$ \\
\hline & & Rendah & 0 & $0,0 \%$ \\
\hline
\end{tabular}

Anak Sulung

Mayoritas kemandirian anak sulung berada pada kategoori tinggi yaitu sebanyak $82,5 \%$ atau 63 orang siswa yang berarti anak sulung mampu 
mengembangkan kemandirian secara emosi, perilaku, dan nilai. Sedangkan anak sulung yang berada pada kategori sedang menjadi minoritas sedikitnya 11 orang $(17,5 \%)$, yang berarti bahwa secara umum anak sulung cenderung mampu untuk mandiri secara emosi, perilaku, dan nilai, dan tidak ada anak sulung yang berada pada kategori rendah.

Adapun gambaran kemandirian anak sulung berdasarkan tiga aspek kemandirian yaitu, kemandirian emosi, kemandirian perilaku, dan kemandiriam nilai yaitu sebagai berikut.

Tabel 3 menunjukkan pada aspek kemandirian emosi mayoritas anak sulung sebanyak 40 orang atau $63,5 \%$ berada pada kategori tinggi. Sedikitnya 23 orang atau $36,5 \%$ berada pada kategori sedang, dan tidak ada yang memiliki kategori rendah.

Hal ini berarti pada aspek kemandirian emosi, kebanyakan anak sulung cenderung mampu dalam memandang orang tua bukan sebagai orang yang sempurna, melihat orang tua seperti orang lain pada umumnya, mampu membuat keputusan untuk menyelesaikan masalahnya tanpa mengandalkan orang tua, mampu bertanggung jawab atas keputusan yang diambil, siswa merasa sebagai individu yang memiliki pemikiran dan perasaan yang berbeda dengan orang tuanya dan siswa mampu menjaga privasi.

Dilihat dari Tabel 3 didapatkan hasil pada aspek kemandirian perilaku mayoritas anak sulung sebanyak 42 orang siswa atau $65,1 \%$ berada pada kategori tinggi, sisanya 22 orang atau $34,9 \%$ berada pada kategori sedang, dan tidak ada siswa yang berada pada kategori rendah. Hal ini menggambarkan bahwa sebagian besar anak sulung cenderung memiliki kemampuan yang cukup optimal dalam meyakinan potensi yang dimiliki.

Pada Tabel 3 hasil penelitian pada aspek kemandirian nilai anak sulung menunjukan mayoritas sebanyak 61 anak atau 96,8\% berada pada kategori tinggi, minoritas anak sulung sedikitnya 2 orang atau 3,2\% berada pada kategori sedang, dan tidak ada siswa yang berada pada kategori rendah. Hal ini menunjukkan bahwa sebagian besar siswa sudah yang optimal dalam membedakan yang benar dan yang salah, memiliki keyakinan terhadap nilai keagamaan, bertindak sesuai dengan prinsip yang dapat dipertanggung jawabkan dalam bidang nilai, bertindak sesuai keyakinan dalam nilainya sendiri.

\section{Anak Tengah}

Tabel 2 menunjukkan sebagian besar anak tengah yaitu sebanyak $79,2 \%$ atau 19 orang berada pada kategori tinggi. Sebagian kecil anak anak tengah yaitu sedikitnya $20,8 \%$ anak tegah atau 5 orang termasuk kategori sedang, dan tidak 
ada anak sulung yang termasuk kategori rendah. Maka dari hasil tersebut dapat dinyatakan bahwa anak tengah telah mencapai kemandirian yang optimal.

Pada kemandirian emosi, sebanyak 17 orang anak tengah atau 20,8\% pada kategori tinggi, 7 orang anak tengah atau 29,2\% menjadi minoritas pada kategori rendah, dan tidak anak tengah yang memiliki kategori sedang dalam aspek kemandirian emosi.

Aspek selanjutnya yaitu aspek kemandirian perilaku anak tengah menunjukan kebanyakan anak tengah $75 \%$ atau 18 orang ada pada kategori tinggi, sisanya sedikitnya $25 \%$ atau 6 orang anak tengah ada pada kategori sedang, dan tidak terdapat anak tengah yang ada pada kategori rendah pada kemandirian perilaku.

Dilihat dari tabel 3 tersebut mayoritas kemandirian nilai anak tengah sebanyak 23 orang atau $95,8 \%$ pada kategori tinggi, minoritas anak tengah sedikitnya 1 orang atau $4,2 \%$ pada kategori sedang, dan tidak terdapat anak tengah yang memiliki kategori rendah dalam aspek kemandirian nilai.

Dari hasil tersebut maka tingkat kemandirian anak tengah telah optimal baik dari aspek kemandirian emosi, kemandirian perilaku, dan kemandirian nilai. Hal tersebut menunjukan bahwa anak tengah dengan kemandirian yang baik memiliki kemampuan, melepaskan ikatan emosional dari orang tua, dapat mengambil keputusan, dapat menyesuaikan diri terhadap berbagai pengaruh orang lain, dan memiliki rasa percaya diri untuk melaksanakan setiap keputusan berdasarkan prinsip-prinsip yang dimilikinya.

\section{Anak Bungsu}

Mayoritas kemandirian secara umum anak bungsu berada pada kategori tinggi dengan jumlah 20 atau 60,6\% dengan kategori tinggi, kemudian minoritas anak bungsu sedikitnya terdapat 13 orang atau $39,4 \%$ dengan kategori sedang, dan tidak ada anak bungsu dengan kategori kemandirian rendah.

Pada Tabel 3 dapat diketahui gambaran kemandirian emosi anak bungsu $57,6 \%$ atau 19 orang ada pada kategori tinggi, kemudian sisanya $42,4 \%$ atau 14 anak bungsu ada pada kategori sedang, dan tidak anak anak bungsu yang memiliki kategori rendah pada aspek kemandirian emosi.

Aspek kemandirian perilaku didapatkan hasil mayoritas anak bungsu sebanyak $75,8 \%$ atau 25 orang ada pada kategori sedang. Sisanya sedikitnya $24,2 \%$ atau 8 anak bberada pada kategori tinggi, dan tidak ada anak bungsu yang berada pada kategori rendah pada aspek kemandirian perilaku. 
Tabel 3 menunjukan hasil bahwa mayoritas anak bungsu sebanyak $97 \%$ atau 32 orang ada pada kategori tinggi, kemudian menjadi minoritas 1 anak bungsu atau $3,0 \%$ berada pada kategori sedang, dan tidak ada anak bungsu yang memiliki kategori rendah dalam aspek kemandirian nilai.

Berdasarkan hasil pemaparan diatas dapat disimpulkan bahwa kemandirian perilaku siswa dengan urutan kelahiran, anak sulung, anak tengah, maupun anak bungsu tidak jauh berbeda, rata-rata terdapat pada kategori tinggi. Siswa dengan urutan kelahiran anak sulung, anak tengah, dan anak bungsu ada pada kategori tinggi artinya mereka telah mencapapai kemandirian yang optimal pada setiap aspeknya, yiatu mampu mengambil keputusan (changes in decision making abilities), mampu menolak pengaruh konformitas dari orang lain (changes in susceptibility and conformity to influence) dan memiliki rasa percaya diri (changes in feelings of self reliance).

Johnson \& Medinnus (Hilman, 2002: 123) menyatakan bahwa faktor urutan kelahiran dalam mempengaruhi perkembangan kepribadian melalui proses sosialisasi dalam keluarga yang mengembangkan kepribadian atau dapat dikatakan terjadi secara tidak langsung melalui adanya kebutuhan manusia akan perhatian dari lingkungannya ketika seseorang masih dalam masa kanakkanak, terutama yang berasal dari orangtua. Lebih lanjut, Johnson \& Medinnus (Suryantina, 2002: 54) mengatakan bahwa untuk berlatih mandiri, orang membutuhkan perasaan aman, suasana penuh perlindungan, penghargaan, cukup kasih sayang dan perhatian dari orang tua, jauh dari perasaan cemburu, tersaigi, cemas, khawatir. Semua kondisi tersebut akan memberikan perasaan aman bagi anak untuk berani berinisiatif, mendorong berlatih tanggung jawab, dan berlatih menyelesaikan masalah-masalah yang dihadapi.

Terdapat perlakuan yang demokratis anak didorong untuk memegang peran yang dipilihnya sendiri dan anak didorong untuk berprestasi (Hurlock, 1996: 200). Keluarga yang mempengaruhi kemungkinan paling besar untuk memperlakukan anak secara demokratis adalah keluarga kecil, namun tidak menutup kemungkinan jumlah anak yang banyak dalam keluarga juga menuntut tingkat kemandirian anak tinggi, karena perhatian orang tua lebih fokus pada anaknya yang masih kecil.

Pada penelitian ini ditemukan bahwa tidak ada perbedaan kemandirian perilaku antara anak sulung, anak tengah, dan anak bungsu. Pada penelitian ini semuanya ada pada kategori tinggi. Hal tersebut sesuai dengan hasil penelitian Jihadah (2009: 9) bahwa tidak adanya perbedaan kemandirian dilihat dari urutan kelahiran baik anak pertama, anak tengah, maupun anak bungsu. Sama halnya dengan penelitian yang dilakukan oleh Utami (2014: 11), tidak ada perbedaan yang signifikan kemandirian ditinjau dari urutan 
kelahiran.Tidak terdapatnya perbedaan yang signifikan tersebut mungkin disebabkan masih ada faktor lain yang perlu dipertimbangkan.

Hal tersebut sejalan dengan penapat Santrock (2003: 150) bahwa urutan kelahiran bukan merupakan satu-satunya faktor yang memengaurhi perkembangan kepribadian seorang remaja. Menurut Santrock masih banyak faktor lain yang lebih penting dalam memperkirakan perilaku seorang remaja termasuk perilaku mandiri.

\section{SIMPULAN}

Berdasarkan urutan kelahiran dalam keluarga, tidak terdapat perbedaan tingkat kemandirian baik anak sulung, anak tengah, dan anak bungsu. Ketiga posisi anak tersebut telah memiliki tingkat kemandirian dengan kategori tinggi.Jadi dapat disimpulkan bahwa tidak terdapat perbedaan kemandirian siswa berdasarkan urutan kelahiran. Artinya, masih banyak faktor lain yang mempengaruhi tingkat kemandirian siswa selain urutan kelahiran dalam keluarga.

Guru Bimbingan dan Konseling dapat memberikan layanan dasar berupa bimbingan klasikal dan bimbingan kelompok kepada siswa sesuai dengan kebutuhan siswa yang berada pada kategori kemandirian tinggi dan sedang untuk mengembangkangkan kemandirian siswa pada setiap aspeknya, yaitu aspek kemandirian emosi, aspek kemandirian perilaku, dan aspek kemandirian nilai.

Peneliti selanjutnya direkomendasikan untuk meneliti kemandirian siswa berdasarkan berbagai faktor-faktor yang mempengaruhinya, diantaranya yaitu pola asuh orang tua, jenis kelamin, sistem pendidikan sekolah, sistem kehidupan di masyarakat, intelegensi, usia, tingkat pendidikan, dan status ekonomi sosial, sehingga dapat menguji variabel-variabel lain yang dapat mempengaruhi perolehan skor kemandirian yang didapat dari siswa.

\section{REFERENSI}

Alwisol. 2004. Psikologi Kepribadian Edisi Revisi. Malang: UMM Press.

Arikunto, S. (2010). Prosedur Penelitian Suatu Pendekatan Praktik. Bandung: Rineka Cipta.

Aprilia, I. D., \& Biasa, J. P. L. (2009). Pengembangan Kemandirian Remaja Tunarungu. JASSI ANAKKU, 8(2), 117-127. 
Asrori, M., \& Ali, M. (2009). Pskologi remaja perkembangan peserta didik. Jakarta: Bumi Aksara.

Azwar, S. (2012). Penyusunan Skala Psikologi (Edisi 2). Yogyakarta: Pustaka Pelajar.

Budiman, N. (2010). Perkembangan Kemandirian pada Remaja. Bandung: FIP UPI.

Covey, S. R. (2007). Teori dan Praktek dari konseling dan psikoterapi, Bandung: Refika Aditama.

Departemen Pendidikan Nasional. (2008). Penataaan pendidikan profesional konselor dan layanan bimbingan dan konseling dalam jalur pendidikan formal.

Hurlock, E. B. (1978). Perkembangan anak jilid 1, Alih Bahasa: Meitasari T dan Muslichah Z. Jakarta: Erlangga.

Hurlock, E. B. (1980). Psikologi perkembangan. Jakarta: Erlangga.

Hurlock, E. B. (1996). Psikologi perkembangan: suatu pendekatan sepanjang rentang kehidupan. Jakarta: Erlangga.

Hurlock, E. B. (1999). Psikologi perkembangan anak jilid 2. Jakarta: Erlangga.

Hilman. (2002). Kemandirian remaja yang tinggal di panti asuhan ditinjau dari persepsi pelayanan sosial dan dukungan sosial (Tesis, Universitas Gadjah Mada).

Hjelle, L. A., \& Ziegler, D. J. (1992). The phenomenological perspective in personality theory: Carl Rogers. Personality theories: Basic assumptions, research, and applications. New York: McGraw-Hill.

Irwanto. (1994). Teori Motivasi dan Aplikasinya. Jakarta: Bina Aksara.

Jihadah, U. (2009). Kemandirian remaja akhir ditinjau dari urutan kelahiran dan status sosial ekonomi orang tuanya (Skripsi, Universitas Gadjah Mada).

Leman, K. (2001). The new birth order book. Jakarta: Tunas Pustaka.

Mind, V. (2003). Misteri perilaku anak sulung, tengah, bungsu, dan tunggal. Jakarta: Gramedia Pustaka Utama.

Natawidjaja, R. (1987). Pendekatan-pendekatan penyuluhan kelompok. Bandung: Diponegoro.

Primana, M. D. S. (2015). Hubungan urutan kelahiran dalam keluarga dengan kemandirian dalam pemenuhan ADL (Activity Daily Living) pada anak usia 4-6 tahun di TK Budiharjo Ngusikan Kabupaten Jombang (Skripsi, Sekolah Tinggi Ilmu Kesehatan Majapahit). 
Prayitno, E. A. (2004). Dasar-dasar bimbingan dan konseling. Jakarta: Rineka Cipta.

Reksoatmodjo, T. N. (2009). Statistika untuk Psikologi \& Pendidikan. Bandung: Refika Aditama.

Puspitorini, A. R. (2012). Kemandirian remaja berdasarkan urutan kelahiran. Jurnal Pelopor Pendidikan, 3(1), 61-70.

Steinberg, L. (1993). Adolescence. Third Edition, New York: McGraw-Hill.

Steinberg, L. (1995). Adolescene. San Francisco: McGraw-Hill.

Steinberg, L. (2002). Adolescence. $6^{\text {th }}$ Ed. USA: McGraw Hill Higher Education.

Suryantina, E. H. (2002). Kemandirian Ditinjau dari Kebutuhan Berafiliasi dan Urutan Kelahiran pada Remaja (Skripsi, Universitas Gadjah Mada).

Utami, O. T. (2014). Kemandirian Ditinjau Dari Urutan Kelahiran dan Jenis Kelamin. (Skripsi, Universitas Muhammadiyah Surakarta).

Wulanningrum, D. N. (2011). Hubungan antara Urutan Kelahiran dalam Keluarga dengan Kecerdasan Emosional pada Remaja di SMA Muhammadiyah I Klaten. Jurnal Kesehatan, 4(2), 184-194.

Yudha, B. P. (2012). Hubungan antara persiapan belajar dengan kecemasan dalam menghadapi ujian pada siswa di SMAN XXX Padang. Psyche 165 Journal, 5(1), 23-26.

Yusuf, S. L. N., \& Nurihsan, A. J. 2005. Landasan bimbingan dan konseling. Bandung: Remaja Rosdakarya. 